\title{
THOMAS FRANKLIN HOLGATE 1859-1945
}

The death of Thomas F. Holgate on April 10, 1945, at the age of eigthy-six years, marks the passing of another of the figures prominent in the early history of the Society. He was one of the organizers of the Chicago Section, and was its first secretary, serving in that capacity for eight years. Although the press of administrative work thereafter lessened his active participation, he missed but few meetings of the Society in Chicago up to the time of his death.

His early life was spent in Canada, where he was born, not far from Kingston, on April 8, 1859. From the University of Toronto he received a bachelor's degree in 1884 and a master's degree in 1889 . Meantime he had been teaching, first in rural schools, then in a collegiate institute. At the end of his work at Toronto he had definitely decided to become a mathematician in the field of pure geometry, in spite of a comparatively late start. The next year he enrolled as a graduate student at Clark University, and obtained his doctor's degree there in 1893.

At Clark he had formed a close friendship with Henry S. White. The latter had come to Northwestern University in 1892, replacing, in the course of that year, E. H. Moore, who had accepted the headship of the department of mathematics in the newly founded University of Chicago. When this vacancy developed, White urged Holgate to come to Evanston, and in 1893 the latter began his career at Northwestern, which was to last for fifty-two years, as professor of mathematics, dean of the college, acting president of the university, and finally as dean emeritus.

Dean Holgate was fond of quoting John Bunyan's line, "I was once a promising professor," thus referring to the nine years from 1893 to 1902 before he started on the administrative work of his next seventeen years. To this time belong his published papers on various subjects in pure geometry, including ruled surfaces of the fourth order, and loci determined in part by imaginary elements. He had been inspired by Reye's Geometrie der Lage, a translation of which he published in 1898. To the same period belongs his text Elementary geometry, plane and solid, following the Euclidean form of presentation. At a later time, in 1911, he wrote the monograph on Modern pure geometry in J. W. A. Young's Monographs on modern mathematics. For many years thereafter he was developing and recasting his ideas on this subject. The final result was his text on Projective pure geometry, published in 1930 . 
In 1902 he became dean of the College of Liberal Arts. From that time on his opportunity to do mathematical work was more and more limited. In 1904 he was a secretary of the geometry section of the mathematical congress at St. Louis, and in 1908 he acted as a secretary of the International Congress of Mathematicians at Rome.

A new responsibility was added to his duties as dean when, in 1904, the president of the university, E. J. James, unexpectedly resigned to take a similar post at the University of Illinois. For the two years 1904-1906, Dean Holgate, as acting president, carried the university through a critical period when substantial funds were obtained without which the development of the institution would have been seriously checked. In 1905 Professor White resigned his headship of the department of mathematics to go to Vassar. These cumulating responsibilities led Dean Holgate, with great regret, to give up the secretaryship of the Chicago Section, a post thereafter filled so capably by $\mathrm{H}$. E. Slaught. He retained, however, his titular headship of the department of mathematics for nearly twenty years. The writer, as acting head during that period, found the relation an ideal one, terminated only at Dean Holgate's request that he be allowed to drop the title.

In the trying years from 1916 to 1919 he was again called to be acting president of the university. His sound judgment and administrative ability brought Northwestern through what seemed then to be a crisis, but proved to be the beginning of a period of unprecedented expansion and addition to resources. The strain was great, and at the age of sixty, in 1919, he retired from both the presidency and deanship with the title of dean emeritus. He did not cease teaching, however, until he reached the age of seventy-five, and his active interest in the department of mathematics continued until his death. In his last years he prepared a history of the department, with some account of the well known mathematicians who had studied or taught there before 1910 (E. H. Moore, J. W. Young, W. H. Bussey, L. L. Dines, C. S. Slichter, among others).

His later year's of teaching included the year 1921-1922 at the University of Nanking. He had always been deeply interested in foreign students, and returned to Northwestern to become more than ever their guide and friend, and even financial helper.

If he had never undertaken administrative work, Dean Holgate would still have been notable as a teacher. He was a master of presentation, with a fine sense of proportion, and a feeling that what he taught was significant and important.

He is best known, however, to thousands of Northestern alumni, 
as "the Dean," who somehow, in their student years, managed to be the friend and adviser of every one of them, and never forgot their names or faces. "Nothing human was foreign to him"; his life was made up of friendships, where he always gave more than he took. We of the faculty remember him best thus, but we cannot forget, either, his wise advice and practical sense, and judgment of men. In spite of his kindliness he had a firmness of character that once drew from a colleague the remark, "There he stands, like a rock."

No account of Dean Holgate could omit his many activities outside the University. He was particularly interested in the Methodist Church, serving five times as an active and prominent member of its quadrennial General Conference. He became deeply interested in negro colleges, advising and visiting them frequently, and helping in their financial affairs. He was a member of the Church Board of Education for over twenty years, and for a time its treasurer. During the years 1923-1925 he was president of the Chicago Church Federation. In 1917-1918 he was president of the North Central Association of Colleges and Secondary Schools. This is by no means a complete list of his activities. He was never one to rust away, even in his old age. He used to say, with a touch of self-deprecating humor, that as he grew older he became busier and busier-on less and less.

During his life he received many honors, among them L.L.D. degrees from the University of Illinois (1905), Queen's University (1919), and Northwestern University (1937). A far greater tribute was the respect and affection of students and colleagues, and of his wide circle of friends outside the university.

D. R. Curtiss 